\title{
The Effects of Immigration on Wages: An Application of the Structural Skill-Cell Approach
}

\author{
Michael Gerfin $^{a}$ and Boris Kaiser ${ }^{b}$
}

JEL-Classification: E24, F22, J61, J31

Keywords: immigration, wages, labour demand, labour supply, skill groups, elasticity of substitution

\section{Introduction}

The effects of immigration on domestic labour markets has been a persistent and fiecely debated issue in many industrialized countries. In particular, there has been much debate among economists and policymakers alike as to whether immigration has a negative impact on native labour market outcomes. It is generally argued that the arrival of foreign workers may bring about an increased level of competition among job seekers, thus worsening the position of domestic workers by driving down wages or causing higher unemployment.

From an economic viewpoint, it is important to distinguish between macroeconomic and microeconomic effects. Regarding the former, a traditional labour market model would imply that a sudden increase in immigrant labour lowers the amount of physical capital available per labour unit which decreases the marginal product of labour and thus average national wages. The question immediately arises whether physical capital responds to such a labour market shock and how fast it will take place. A partial adjustment of physical capital will cushion the fall of the capital-labour ratio. It is therefore clear that any macroeconomic impact of immigration depends on the dynamic response of physical capital accumulation. The more microeconomic aspect of the question has received more attention by labour economics and deals with the effects of immigration on the wages of individual workers. A traditional textbook analysis that considers a labour market with homogenously skilled workers implies that an increase in supply

a Department of Economics, Public Economics, University of Bern, e-mail: michael.gerfin@ vwi.unibe.ch.

b Department of Economics, Public Economics, University of Bern, e-mail: boris.kaiser@vwi. unibe.ch. 
leads to a new equilibrium with lower wages. However, if labour is heterogeneous such that different types of workers are imperfect substitutes (or even complements) for one another, an increase in the supply of one type of worker may raise labour demand for another type of worker, and thus, their wages. In other words, some workers might benefits from a particular influx of foreign workers, while others might lose. For example, an increase in low-skilled immigrants can have starkly different implications for low-skilled natives vis-à-vis high-skilled natives. As individual workers are likely to be asymmetrically affected by immigration, one should attempt to gauge the distributional effects across different groups of workers. Such an analysis requires a model that enables the researcher to categorize workers into different skill groups. The interrelationships between these groups are captured by elasticities of substitution. This form of analysis is usually referred to as the structural "skill-cell" approach. In employing this approach, these elasticities of substitution play a very crucial role as they govern the direct effects and the cross effects triggered by changes in the supply of different types of workers.

In recent years, there have been an increasing number of empirical studies using the skill-cell approach to estimate how immigration affects domestic wages. Previous studies often used city-level or state-level data to exploit spatial correlations. This method, however, is prone to a number of problems including internal native migration responses, endogeneity of immigrants' destination, and so on (BoRJAs et al, 1997). In contrast, the skill-cell method constitutes a "national" approach in the sense that the country's entire economy is considered. The findings of previous studies are somewhat mixed. While, for example, BorJas (2003) and BorJas et al (2008) find that immigration has exerted significant downward pressure on wages of low-skilled U.S.-born workers, Ottaviano and Peri (2006), OtTaViano and Peri (2008) report benign effects on natives' wages but a sizable negative impact on previous immigrants' wages. Overall, most evidence suggests that the total long-run effect on native workers seems to cluster around zero, but across skill groups there may be significant differences.

The aim of this paper is twofold. First, we will follow the skill-cell approach in the tradition of Borjas (2003) and Ottaviano and Peri (2006), OttaviANO and PERI (2008) to estimate the elasticities of substitution between different types of workers in Switzerland. Second, these empirical estimates will then be employed to simulate the impact on domestic wages using the actual immigration inflows from 2002 to 2008. Section 2 contains some concise facts on immigration in Switzerland. Section 3 presents an overview of the economic literature that deals with the wage effects of immigration. In particular, it is explained which methods are used and what results have been obtained. In Section 4, we establish 
a theoretical framework based on a production function with a nested CES structure for the labour aggregate so that workers can be differentiated according to their skill level and their nativity. To take into account the macroeconomic consequences of immigration, we also consider the adjustment process of physical capital as a response to the observed foreign labour supply shocks. Section 5 deals with the dataset and the construction of skill cells and variables. In addition, a selected number of descriptive statistics is presented. Section 6 summarizes our empirical estimates of the elasticities of substitution in the model. Section 7 simulates the wage effects of immigration and considers several scenarios of capital adjustment. Section 8 addresses some important problems and limitations that are prevalent with the approach applied in this paper.

\section{Immigration in Switzerland}

In this short section, we will present some facts about immigration in Switzerland. In particular, it is shown how the nature and the magnitude of immigration into Switzerland have changed over time. Unless otherwise indicated, the relevant data and information is drawn from Haug and Müller-Jentsch (2008) and the latest report from the State Secretariat for Economic Affairs SECO (2009). According to the $\mathrm{OECD}^{1}, 24.9 \%$ of the Swiss population were born abroad and $20.8 \%$ do not have Swiss citizenship (in 2007). These numbers are similar to some of the traditional immigration countries, such as Australia, New Zealand and Canada, but they are much higher than in most other European OECD countries. For example, the share of the foreign-born population is $13 \%$ in Germany (in 2003), 8.5\% in France and 10\% in the United Kingdom.

From a recent historical perspective, there have been several waves of immigration into Switzerland. From 1950 to 1970, Switzerland's economy experienced a period of rapid expansion with high growth rates. There was an increasingly strong demand of domestic firms for cheap labour that domestic labour supply could not meet. Consequently, many foreign workers, predominately from Italy and to a lesser extent from Spain, were drawn into Switzerland. During these twenty years, the number of non-Swiss residents increased from 0.3 million to roughly 1.15 million. This large influx was largely due to domestic labour market conditions, that is, "pull-factors". During the 1970s, many migrant workers had

1 http://www.oecd.org/statisticsdata/0,3381,en_2649_37415_1_119656_1_1_37415,00.html. 
to return to their home countries as Switzerland slipped into recession in the wake of the oil crisis in 1973. The number of foreign residents declined to less than 1 million. It was not until the second half of the 1980s that immigration started to rise again, but there was a clear shift to other source countries: new immigrants mainly came from former Yugoslavia, Turkey and Portugal. An important "push-factor" for large-scale immigration from former Yugoslavian countries was clearly the Yugoslav wars in the 1990s.

Since 2000, there has been a marked shift in immigration towards EU-27/ EFTA countries, while the number of new immigrants from other countries has been declining. This development can largely be ascribed to changes in Swiss immigration policies. Switzerland greatly eased immigration restrictions for EU/ EFTA nationals as the bilateral agreement with the EU on the free cross-border movement of workers (Abkommen zur Personenfreizügigkeit) came into effect in 2002. In particular, there have been a rapidly increasing number of new immigrants from Germany and Portugal. The former group accounts for $66 \%$ and the latter group for $20 \%$ of net immigration originating from EU/EFTA countries. Due to this shift, it appears that the nature of most recent immigration flows better serves the needs of the domestic economy than previous flows (in the 1980s and 1990s) because immigration is more directly linked to the labour market. In fact, growing employment in recent years is to a considerable degree associated with the influx of foreign workers. According to the Federal Office of Statistics $(\mathrm{BFS})^{2}$, the number of employed persons (Erwerbstätige) rose by 462,000 from 2000 to 2008, and 56\% of this change is explained by the increase in foreign workers. From 1990 to 1999, the stock of employed persons rose by only 218,000 , while the number of foreign workers actually declined by 6,000 (which corresponds to a negative contribution to growth of $-3 \%$ ). These numbers clearly illustrate that immigrants in the 1990s had a much looser labour market attachment compared to the more recent inflows. Furthermore, this is reflected in the fact that new immigrants are much better educated on average. Between 1997 and 2007 , around $50 \%$ of new immigrants are reported to have tertiary education, while during the 10 years before that, this share was only half as large. Total net immigration of foreign nationals has generally trended upwards since 1997 and has risen sharply in 2007 and $2008^{3}$.

2 http://www.bfs.admin.ch/bfs/portal/de/index/themen/03/02/blank/data/01.Document.64612. xls.

3 http://www.bfs.admin.ch/bfs/portal/de/index/themen/01/06/blank/key/01.html. 


\section{Overview of the Literature}

When it comes to analyzing empirically how immigration affects domestic wages, there are two major approaches that can be found in the literature. The first one is referred to as the "spatial correlations method" or sometimes "area approach", which exploits correlations between immigrant concentrations and wages across geographic regions while controlling for a host of other determinants of wages. The second and more recent approach is often referred to as the "skill-cell method", which focuses on the national labour market and treats skill groups as heterogenous factors of production. In this section, we will briefly present an overview as to how these two methods have been applied in the literature.

\subsection{The Spatial Correlations Method}

Most studies using the spatial correlations method only find modest effects of immigration on natives' labour market outcomes (e.g. LALONDE and Topel, 1991; Altonji and Card, 1991; De New and Zimmermann, 1994; and Pischke and VeLLING, 1997). However, there are a number of problems associated with this approach. First, immigration flows and wages can suffer from a simultaneity bias. If foreign workers tend to move to places where wages are high, immigration is endogenous to local labour market conditions. Put simply, immigration affects wages, but wages also affect immigration. Quasi-natural experiments (e.g. CARD, 1990) or IV strategies can offer a solution to this simultaneity problem. Second, Borjas et al (1996) argue that the effects of immigration tend to diffuse across the boundaries of the spatial unit, i.e. the city or the state. For instance, natives might respond to immigration by moving to other cities or by entering new occupations. Such responses would naturally offset the measured impact on natives' wages. To avoid these difficulties, they therefore conclude that one should focus on the national labour market to measure how immigration affects domestic labour market outcomes.

\subsection{The Skill-Cell Method}

In light of the above-mentioned problems attached to the spatial correlations method, researchers began focusing on national labour market data instead of city-level or state-level data. This approach gained momentum after the seminal work of BorJas (2003). He categorizes workers in cells according to their education and work experience. Using national panel data, BorJAs' (2003) regression results imply that a $10 \%$ increase in immigrants lowers average weekly earnings 
by $4 \%$. In contrast, if skill cells are defined by state, the impact of immigration is smaller by two thirds. He sees this as strong evidence that the spatial approach obscures the true magnitude of the immigration effect. BorJas (2003) most important contribution is the specification and application of a structural model based on a production function with a nested CES structure. This framework explicitly captures the interrelationships between various skill cells through several elasticities of substitution. Borjas uses his own estimates of the elasticities between different education and experience groups to calculate the wage effects. He finds that the immigration influx into the U.S. from 1980 to 2000 reduced average real wages by some $3 \%$. Most dramatically, his simulations predict that high school dropouts experienced wage declines of almost 9\%. These numbers suggest a much stronger adverse impact of immigration than virtually all spatial correlations studies.

However, Ottaviano and Peri (2006) point out some important limitations of Borjas (2003) approach that they correct for in their paper. First, they lift Borjas' restrictive assumption that natives and immigrants are perfect substitutes. They argue that immigrants differ systematically in their skills and preferences and therefore choose different types of jobs in the labour market. Indeed, their empirical estimates confirm an imperfect degree of substitutability between nativity groups. Second, Ottaviano and Peri (2006), Ottaviano and Peri (2008) relax Borjas (2003) assumption of a fixed capital stock. Instead, their model takes into account that physical capital adjusts to increases in labour supply. Their argument is supported by long-term data on the capital-labour ratio that appears to follow a balanced growth path. Third, they simulate the wage effects taking into account all cross-elasticities implied by the model. In this way, changes in supply of one type of worker can also affect labour demand of all other types of workers. In contrast, BoRJas (2003) uses the partial elasticity that only considers the changes in supply occurring in the same skill cell. As a further refinement, Ottaviano and Peri (2008) relax the constraint that the elasticity of substitution between education groups must be the same for all groups. Their estimation results imply that low-educated and highly-educated workers have much higher (possibly infinite) within-group elasticities than workers across these broad groups. Their long-run simulations predict that immigration from 1990 to 2004 had small positive effects on natives' wages $(+0.6 \%)$ but detrimental effects on previous immigrants' wages $(-6.4 \%)$.

A number of studies focus on European labour markets. For Great Britain, MANACORda et al. (2006) report that a $10 \%$ rise in all immigrants raises the native-immigrant wage differential by $2.3 \%$. Studies on Germany include Brücker and Jahn (2008), Felbermayr et al. (2008) and D’Amuri et al. (2009). 
On the whole, these studies find small positive effects for natives and negative effects for previous immigrants in the long run. Allowing for wage rigidities due to the more sclerotic labour market, they report that a negative impact on unemployment induced by immigration partially offsets a decline in wages.

From this brief overview, it has become clear that the literature provides no clear consensus on the wage effects of immigration. For the most part, however, researchers have found rather small adverse effects or no significant effects.

In reflecting the current state of research, Bodvarsson and VAN DEN BERG (2009) argue that economists still neglect important adjustment processes. Most importantly, they stress that immigration affects the demand side of the economy. That is, new immigrants certainly increase aggregate demand since they spend some of their earnings on locally-produced goods and services. In this way, they will automatically boost domestic labour demand of firms and therefore also influence wages. Empirical studies by Bodvarsson and VAN DEN BERG (2006) and Bodvarsson et al. (2008) find clearly positive consumer demand effects induced by immigration that increase the average wage of local workers. Moreover, immigration may also affect the rate of economic growth if they raise the average education level of the population (cf. BARro, 2001).

\section{Theoretical Framework}

This section will introduce a theoretical framework that constitutes the basis for our empirical analysis. The model is largely based on Ottaviano and Peri (2008), where workers with different education, work experience and nativity are allowed to be imperfect substitutes. Moreover, the model builds on a general equilibrium framework in which factor prices of labour and capital equal their marginal products.

\subsection{Production Function}

We consider a neoclassical framework in which firms operate on perfectly competitive markets and maximize profits such that all factors are paid their marginal products. As in Borjas (2003), Ottaviano and Peri (2008), D'Amuri et al. (2009), we specify the production function of the economy in the widely used Cobb-Douglas form:

$$
Y_{t}=A_{t} N_{t}^{\alpha} K_{t}^{1-\alpha}
$$


where $Y_{t}$ is aggregate output, $A_{t}$ is total factor productivity (TFP), $K_{t}$ is the physical capital stock and $N_{t}$ is the CES aggregate containing all types of labour input. The subscript $t$ denotes the time period. This functional form implies that $\alpha \in(0,1)$ corresponds to the income share of the labour aggregate and is assumed to be constant over time. ${ }^{4}$

As mentioned above, $N_{t}$ represents the aggregate labour input. Since our neoclassical framework assumes flexible wages, labour markets clear in every period $t$, so that aggregate labour demand equals aggregate labour supply. (In Section 8.2, the implications of these assumptions will be discussed.) $N_{t}$ has a nested CES structure that combines labour supply of different education and experience groups as well as labour supply of native and foreign workers. On the first level, it can be disaggregated as follows:

$$
N_{t}=\left[\theta_{H t} N_{H t}^{\varepsilon}+\theta_{L t} N_{L t}^{\varepsilon} H L\right]^{1 / \varepsilon} H L,
$$

where $N_{H t}$ and $N_{L t}$ measure the labour inputs by individuals with high and low education, respectively, in period $t$. The parameters $\theta_{H t}$ and $\theta_{L t}$ are the corresponding productivity parameters that capture the relative efficiency of the labour aggregates in the production process. We constrain them to add up to unity, i.e. $\theta_{H t}+\theta_{L t}=1$, so that any common productivity shock will be absorbed by TFP. The parameter $\varepsilon_{H L}$ equals $\left(\sigma_{H L}-1\right) / \sigma_{H L}$, where $\sigma_{H L}$ is the elasticity of substitution between highly-educated and less-educated labour.

As in Ottaviano and Peri (2008), the lower levels of the CES labour aggregate are specified as follows:

$$
\begin{aligned}
& N_{L t}=\left[\theta_{L 1 t} N_{L 1 t}^{\varepsilon_{L}}+\theta_{L 2 t} N_{L 2 t}^{\varepsilon_{L}}\right]^{1 / \varepsilon_{L}} \\
& N_{H t}=\left[\theta_{H 1 t} N_{H 1 t}^{\varepsilon_{H}}+\theta_{H 2 t} N_{H 2 t}^{\varepsilon_{H}}\right]^{1 / \varepsilon_{H}} \\
& N_{b k t}=\left[\sum_{j=1}^{4} \theta_{b k j} N_{b k j t}^{\varepsilon_{X}}\right]^{1 / \varepsilon_{X}} \\
& N_{b k j t}=\left[\theta_{D b k j t} N_{D b k j t}^{\varepsilon_{I}}+\theta_{F b k j t} N_{F b k j t}^{\varepsilon_{I}}\right]^{1 / \varepsilon_{I}}
\end{aligned}
$$

4 This assumption is supported by Swiss national data (see http://www.bfs.admin.ch/bfs/portal/ de/index/themen/04/02/01/key/bip_nach_einkommensarten.Document.64629.xls), since the labour income share of GDP has roughly been around 62 percent for the last 20 years and never deviated more than 2 percentage points from this value. 
Equations (3) and (4) split up each broad education group into two subgroups $k \in\{1,2\}$. The parameter $\varepsilon_{b}=\left(\sigma_{b}-1\right) / \sigma_{b}$ captures the degree of substitutability within group $b \in\{L, H\}$, with $\sigma_{b}>0$ being the elasticity of substitution between group $b 1$ and $b 2$. We assume that all workers within the high-education group are perfect substitutes and equally productive, such that $\sigma_{H}=\infty$ and $\theta_{H 1 t}=\theta_{H 2 t^{\circ}}{ }^{5}$ As a consequence, expression (4) collapses to $N_{H t}=\theta_{H t}\left(N_{H 1 t}+N_{H 2 t}\right)$. Since $H 1$ and $H 2$ form a homogenous group, it will henceforth be referred to as $H 1$ for simplicity.

Equation (5) disaggregates each labour composite $N_{b k t}$ into experience groups, where $N_{b k j t}$ represents the labour aggregate of education group $b k$ and experience group $j$, with $j \in\{1,2,3,4\}$. The parameters $\theta_{b k j}$ indicate time-invariant productivity levels specific to the education-experience groups and their sum is constrained to one. The elasticity of substitution between experience groups is given by $\sigma_{X}=1 /\left(1-\varepsilon_{X}\right)$.

Equation (6) break down each education-experience group $N_{b k j t}$ into native ('domestic') and immigrant ('foreign') labour supply groups, denoted by $N_{D b k j t}$ and $N_{F b k i t}$, respectively. The elasticity of substitution between native and foreign labour is defined as $\sigma_{I}=1 /\left(1-\varepsilon_{I}\right)$.

As pointed out in Section 3, recent evidence suggests for the United States (Ottaviano and Peri, 2006; 2008), Great Britain (Manacorda et al., 2006) and Germany (BrüCKer and Jahn, 2008; Felbermayr et al., 2008; D'Amuri et al., 2009) that native and foreign-born workers are indeed not perfect substitutes even if they have comparable education and experience.

\subsection{Physical Capital Adjustment}

Since markets are assumed to be perfectly competitive, labour is paid its marginal product in equilibrium. Given the production function, the average wage in the economy is given by:

$$
\bar{w}_{t}=\frac{\partial Y_{t}}{\partial N_{t}}=\alpha A_{t} \kappa_{t}^{1-\alpha}
$$

with $\kappa_{t}=\left(K_{t} / N_{t}\right)$. The above expression suggests that a rise in the labour aggregate $N_{t}$ will cause the average wage to fall. In other words, an inflow of foreign workers will, ceteris paribus, lead to a new labour market equilibrium with lower average wages. If we assume that the rate of technological change $A_{t}$ remains

5 This assumption cannot be rejected empirically, see Gerfin and KaISER (2010). 
unaffected by immigration, we can write the (log) change of the average wage as follows:

$$
\left(\frac{\Delta w_{t}}{w_{t}}\right)_{i}=(1-\alpha)\left(\frac{\Delta \kappa_{t}}{\kappa_{t}}\right) .
$$

If capital is perfectly inelastic to changes in labour supply, i.e. $K_{t}=\bar{K}$, the change in the average wage equals $(1-\alpha)\left(-\left(\Delta F_{t} / N_{t}\right)\right.$. However, if immigration triggers capital accumulation, the fall in the average wage is attenuated. This follows from the fact that

$$
\left|\frac{\Delta \kappa_{t}}{\kappa_{t}}\right|<\left|\frac{\Delta F_{t}}{N_{t}}\right|
$$

if

$$
K_{t+1}>K_{t}=\bar{K} .
$$

What are the implications of immigration in the long run? If long-run growth is considered exogenous as in RAMSEY (1928) and Solow (1956), the economy follows a balanced growth path in the long run. In our framework, long-run growth takes place through the increase in TFP, i.e. $A_{t}$. The capital-labour ratio in steady state is then given by

$$
\kappa_{t}^{*}=\left(\frac{1-\alpha}{r+\delta}\right)^{1 / \alpha} A_{t}^{1 / \alpha},
$$

where $r$ is the real interest rate and $\delta$ is the depreciation rate (see, for a more detailed description, Ottaviano and Peri, 2008). This implies that the capital-labour ratio, and thus the average wage, does not depend on labour supply in the long-run. Hence, the long-run impact of immigration on average wages must be equal to zero. However, the nested structure of the aggregate $N_{t}$ in the model implies that wages across labour supply groups will be asymmetrically affected if the inflows of immigrant workers do not spread across skill groups in proportion to the size of these groups. As a result, we can conclude that, while the long-run impact on average wages is zero due to full capital adjustment, the model implies that immigration is likely to have permanent distributional effects across labour supply groups. 
To simulate the dynamics of capital adjustment, one needs to know how fast physical capital will adjust to shocks in the labour market. In Section 7, we will attempt to estimate the speed of convergence directly from Swiss data.

\subsection{Wages in the Labour Market Equilibrium}

In expression (7), we have already derived the average wage level if the labour market is in equilibrium. Expression (8) captures the macroeconomic effect on wages caused by a change in labour supply. However, since we are mainly interested in the distributional effects, we must derive the equilibrium wage for each nativity-education-experience groups in the model. In equilibrium, the wage of a worker with broad education $b \in\{H, L\}$, fine education $k \in\{1,2\}$, experience $j \in\{1,2,3,4\}$ and nativity $n \in\{D, F\}$ is equal to his marginal productivity. Due to the nested structure of the CES labour aggregate, we obtain the wage by differentiating (1) with respect to $N_{n b k j t}$. If we apply the natural logarithm and substitute in the elasticities of substitution $\sigma_{H L}, \sigma_{b}, \sigma_{X}$ and $\sigma_{I}$, the expression can be written as

$$
\begin{aligned}
\ln w_{n b k j t}= & \ln \left(\alpha A_{t} \kappa_{t}^{1-\alpha}\right)+\frac{1}{\sigma_{H L}} \ln N_{t}+\ln \theta_{b t}-\left(\frac{1}{\sigma_{H L}}-\frac{1}{\sigma_{b}}\right) \ln N_{b t} \\
& +\ln \theta_{b k t}-\left(\frac{1}{\sigma_{b}}-\frac{1}{\sigma_{X}}\right) \ln N_{b k t}+\ln \theta_{b k j}-\left(\frac{1}{\sigma_{X}}-\frac{1}{\sigma_{I}}\right) \ln N_{b k j t} \\
& +\ln \theta_{n b j k t}-\frac{1}{\sigma_{I}} \ln N_{n b k j t}
\end{aligned}
$$

The left-hand side of (9) denotes the log of the average wage in group $(n, b k, j)$, and the terms on the right-hand side show how the components of the nested production function affect the wage. It is important to note that we assume that total factor productivity $A_{t}$ and the relative productivity parameters, the $\theta$ 's, are not affected by any changes of labour supply. In contrast, the capital-labour ratio and the labour composites are directly affected by an inflow of workers with education $b k$ and experience $j$. On the one hand, there is a macroeconomic effect operating through $\ln \left(\alpha A_{t} \kappa_{t}^{1-\alpha}\right)$ that shows how the average wage in the economy is affected by immigration. As previously pointed out, immigration lowers the average wage if capital adjusts partially but the effect gradually dies out in the course of the capital adjustment process. On the other hand, there are a number of permanent distributional effects due to changes in labour supply operating through the labour composites $N_{t}, N_{b t}, N_{b k t}, N_{b k j t}, N_{n b k j t}$. Due to the 
rather complex nature of the RHS in (9), we discuss the implications of the terms one by one.

The first term

$$
\frac{1}{\sigma_{H L}} \ln N_{t}
$$

constitutes a positive effect on the productivity of all types of workers if aggregate labour supply increases. This is explained by the imperfect substitutability among workers with different skills. The second channel of influence operates through

$$
-\left(\frac{1}{\sigma_{H L}}-\frac{1}{\sigma_{b}}\right) \ln N_{b t} .
$$

It is sensible to conjecture that workers within broad education groups are closer substitutes than across broad groups, i.e. $\sigma_{H L}<\sigma_{b}$. Then, an increase of labour supply in the same broad education group negatively affects the wage. Likewise, if $\sigma_{b}>\sigma_{X}$ holds, the third term

$$
-\left(\frac{1}{\sigma_{b}}-\frac{1}{\sigma_{X}}\right) \ln N_{b k t}
$$

is positive and raises workers' wages in the same education subgroup $b k$ as the immigrant inflow occurs. The implications of the fourth term

$$
-\left(\frac{1}{\sigma_{X}}-\frac{1}{\sigma_{I}}\right) \ln N_{b k j t}
$$

are somewhat more ambiguous; the direction of the effect depends on the substitutability between experience groups relative to the substitutability between nativity groups. If $\sigma_{X}<\sigma_{I}$, immigration negatively affects the wage in education-experience group $(b k, j)$, but in the opposite case the effect is positive. Finally, the term

$$
-\frac{1}{\sigma_{I}} \ln N_{n b k j t}
$$


suggests that an increase of workers with nativity $n$ has a negative impact on workers' wages in the same nativity group. This is to say, that, given native and foreign workers are imperfect substitutes, an immigrant influx has a stronger negative effect on immigrants' wages than on natives' wages even if they are located within the same education-experience group. In other words, new immigration is more detrimental for previous immigrants if they are not perfect substitutes for natives.

The analysis has made clear that the effect of immigration on wages works through the complex and nested structure of the production function, where workers' marginal productivity is not only affected by changes in supply in the same skill cell, but also by changes in all other skill cells. What is more, we have seen that the magnitude and the direction of the effects on wages heavily hinge on the elasticities of substitution $\sigma_{H L}, \sigma_{b}, \sigma_{X}$ and $\sigma_{I}$.

\section{Data}

This section provides the relevant information about the datasets used for estimation. Second, it will be explained how skill cells are constructed and how average weekly wages and labour supply measures are computed for each cell. Finally, descriptive statistics are presented.

\subsection{Dataset}

To perform empirical estimation of the structural model presented in the previous section, we elicit all the required data from the Swiss Workers Survey (Schweizerische Arbeitskräftebefragung, short: SAKE). The data has been gathered by means of telephone interviews. The dataset provides annual data for the time span from 1991 to 2008 . The sample size varies considerably from roughly 16,000 to 48,000 observations, where older waves are generally smaller than more recent ones. For our purposes, we only consider men and women aged between 18 and 64, and only those who are currently employed, thus dropping all selfemployed, unemployed and early retirees.

\subsection{Construction of Skill Cells and Variables}

To implement the model empirically, we need to categorize and assign workers to cells according to nativity ("native" or "immigrant"), education and work experience. This subsection will explain how we allot workers to the respective cells. 
First, we assign workers to cells by nativity and either categorize them as being "natives" or "immigrants". For this purpose, we apply a simple rule and define native workers as those holding Swiss citizenship. Therefore, previously naturalized individuals are also categorized as natives. In contrast, Swiss residents who only hold foreign passports are defined as immigrants. Second, we assign all individuals to one of our 3 education groups. The crucial criterion here is the highest degree attained at the time of data collection. The low education group $(b k=L 1)$ includes all people who have completed mandatory schooling or dropped out before completion. In addition, we add those who had minor job training of one or two years (Anlehre). Individuals are assigned to the medium education group $(b k=L 2)$ if they hold vocational degrees (Berufslehre) or upper secondary school diplomas (Maturität, Berufsmaturität). The high education group $(b k=H 1)$ includes all workers with higher vocational training (höhere Fachschule, Technikerschule) and those with college or university degrees (Fachhochschule, Universität). Third, we need to construct a measure of potential work experience, since we do not have explicit data on how long individuals have been active in the labour market. For this reason, we use the individual's current age and subtract the age at which he is expected to have completed his education. The computation relies on the average duration of schooling which is required to obtain the educational degree that person $i$ holds. It is important to note that this procedure results in a somewhat crude measure of work experience, since employers may evaluate immigrants' experience differently. To attenuate the impact of any potential bias, we categorize workers in only 4 but rather broad experience groups, each spanning an interval of 10 years of experience. In contrast, most other studies use 8 experience groups and five-year intervals, e.g. Borjas (2003), Ottaviano and Peri (2006), Ottaviano and Peri (2008), D'Amuri et al. (2009), but they also manage to produce more accurate measures of potential work experience. Having constructed the variable for work experience, we drop individuals whose imputed experience is below zero or above 40 years.

Having assigned all individuals to the respective cell according to their education, experience and nativity, the problem emerges that there are only few observations in some cells in certain years. Especially in the data prior 2002, the cells for highly educated and highly experienced foreign workers contain only very few observations, so that a reliable construction of average wages and labour supply becomes problematic. To alleviate the problem, the following couples of years are pooled together: 1991/1992, 1993/1994, 1996/1997, 1998/1999, and 2000/2001. As a result, the "weakest" cell ( $b k=H 1, j=4, n=F)$ contains never less than 35 observations, and the second-to-weakest cell $(b k=H 1, j=3, n=F)$ contains 
never less than 72 observations. All other cells never include less than 100 observations. All in all, the SAKE data from 1991 to 2008 translate into 13 waves (and thus 156 observations) available to be used for estimation.

As a next step, we produce a measure of average weekly real wages, hours worked and employment for native and immigrant workers in each nativityeducation-experience cell. For a detailed description as to how these variables are constructed, see Gerfin and KaIser (2010, Appendix A).

\subsection{Descriptive Statistics}

In this subsection, we will provide descriptive statistics of the variables described above. In particular, we focus on immigration from 2002 to 2008 since it marks the time period in which the bilateral agreement on the free movement of people with the EU (Personenfreizügigkeitsabkommen) has been effective. The simulations in Section 7 will also consider the same time span.

Table 1 presents the percentage changes in hours worked with respect to total hours worked for each education group over the period from 2002 to 2008. Columns 1 and 2 show how much of the change in hours worked in a particular education group can be attributed to natives and immigrants, respectively, so that the sum of the two corresponds to the change in total hours worked (column 3) in that group. The numbers in column 2 are most interesting since they reflect the cumulative changes in foreign labour supply that occurred during the period in question. It shows clearly that immigrant inflows did not take place evenly across education group: while the increase in hours worked due to immigration was moderate in the low education group (2.8\%), the high education group experienced a very sizable increase $(13.8 \%)$. In contrast, medium-educated foreign labour slightly declined $(-0.5 \%)$ in terms of total hours worked in that group. On the whole, total foreign labour supply increased by some 3.9\% with respect to total labour supply in 2002. Column 3 indicates that there is a strong composition effect: labour supplied by highly educated individuals rose substantially partly because aggregate labour supply has increased (6.7\%) and partly because labour supplied by the other two education groups fell in absolute terms. The former effect could be due to growth of the labour force, less unemployment or higher average working hours. The latter effect reflects a rising education level of the workforce. 
Table 1: Changes Relative to Total Hours Worked in the Group from 2002 to 2008

\begin{tabular}{lccc}
\hline & $\begin{array}{c}\text { Change due to } \\
\text { native workers }\end{array}$ & $\begin{array}{c}\text { Change due to } \\
\text { foreign workers }\end{array}$ & $\begin{array}{c}\text { Change in total hours } \\
\text { worked }\end{array}$ \\
\hline Low education & $-7.6 \%$ & $2.8 \%$ & $-4.8 \%$ \\
Medium education & $-7.7 \%$ & $-0.5 \%$ & $-8.3 \%$ \\
High education & $30.2 \%$ & $13.8 \%$ & $44.0 \%$ \\
All & $2.8 \%$ & $3.9 \%$ & $6.7 \%$ \\
\hline
\end{tabular}

Table 2 contains the percentage changes in average weekly real wages by nativity and education over the same time period. In addition, it is shown how the relative size of education groups changed with respect to hours worked. (For more detailed data on wages and hours worked across groups, see Gerfin and KaISER (2010, Appendix B) It is important to note that the wage of each person is weighted by her hours worked and corrected for inflation. While native workers within education groups earn lower average wages in 2008 , the average wage among natives roughly stayed constant $(-0.2 \%)$. This is possible because the labour supply share of the highly educated group grew substantially (by 9.7 percentage points), while the labour supply shares of the other groups fell (by -1.6 and -8.1 percentage points). This can be interpreted as follows: well-paid individuals within the lower groups have moved to a higher education group by attaining higher educational degrees. Those who newly entered the high-education group (individuals who completed higher vocational training and college and university graduates) are paid below average compared to the rest of the group and thus reduce the average wage in that group. Hence, the "composition effect" of labour supply left the average wage of natives roughly constant, although average wages within education groups declined significantly. The changes in wages among immigrant workers are much more uneven: average wages of less educated workers declined, while average wages of highly educated workers rose. In total, immigrant workers earned significantly higher wages (+5.5\%) in 2008 compared to 2002. Again, this is to a large extent due to the composition effect of foreign labour supply. On the one hand, some foreign individuals may have moved to a higher education group through higher educational attainment. On the other hand, many highskilled workers (mostly from Germany) entered the Swiss labour market during the period, and thus raised the average wage in that group. Moreover, since the share of low educated and low-paid workers is high among immigrants, the relatively high-skilled influx led to a sizable increase in average wages of immigrants. 
Table 2: Change in Wages and Shares of Hours Worked from 2002 to 2008

\begin{tabular}{|c|c|c|c|c|}
\hline \multirow[t]{2}{*}{ Education group } & \multicolumn{2}{|c|}{ Natives } & \multicolumn{2}{|c|}{ Immigrants } \\
\hline & $\begin{array}{c}\text { Change in aver- } \\
\text { age weekly real } \\
\text { wages }\end{array}$ & $\begin{array}{l}\text { Percentage point } \\
\text { change in the } \\
\text { share of hours } \\
\text { worked }\end{array}$ & $\begin{array}{l}\text { Change in } \\
\text { average weekly } \\
\text { real wages }\end{array}$ & $\begin{array}{c}\text { Percentage point } \\
\text { change in the } \\
\text { share of hours } \\
\text { worked }\end{array}$ \\
\hline Low & $-6.1 \%$ & -1.6 & $-4.3 \%$ & -2.8 \\
\hline Medium & $-4.0 \%$ & -8.1 & $-0.1 \%$ & -7.4 \\
\hline High & $-4.8 \%$ & 9.7 & $1.8 \%$ & 10.2 \\
\hline All & $-0.2 \%$ & & $5.5 \%$ & \\
\hline
\end{tabular}

Notes: To calculate average weekly real wages, the wage distribution within each education group is trimmed on both ends by one percentile.

By comparing the aggregate summary statistics on hours worked and wages, we cannot draw any conclusions about the effects of immigration on native wages. Even if correlations between foreign labour supply and wages would be discernable, they are likely to be misleading because they fail to uncover the causal relationship between the two variables. After all, the reasons of changes in wages are manifold; they respond not only to labour supply shocks, but are the result of complex and intertwined economic forces at work. They are, among other things, strongly determined by labour demand which, in turn, is influenced by productivity shocks, structural shifts in production, business cycle fluctuations and changes in the institutional framework of the economy. To gain a better understanding as to how the inflows of foreign workers affect domestic wages, we must be able to isolate the effect of immigration. In order to do this, we employ the structural model to estimate the causal effect. Before we can proceed, however, we must estimate the elasticities of substitution in the production function.

\section{Estimating the Elasticities of Substitution}

We estimate the elasticities of substitution by adhering to the standard approach of the recent immigration literature (see e.g. Borjas, 2003; OttaViano and Peri, 2008). For full details on the derivation of estimating equations, the estimation procedure and the results, the reader is referred to the working paper version Gerfin and Kaiser (2010). 
Table 3 below summarizes the preferred values of the various elasticities of substitution that we obtained from estimation. These are the values used in the simulation in Section 7.

Table 3: Elasticities of Substitution

\begin{tabular}{lccccc}
\hline & $\sigma_{I}$ & $\sigma_{X}$ & $\sigma_{H L}$ & $\sigma_{H}$ & $\sigma_{L}$ \\
\hline preferred value & 10 & 10 & 3.7 & $\infty$ & $\infty$ \\
\hline
\end{tabular}

\section{Simulating the Effects of Immigration from 2002 to 2008}

This section will now make use of the estimated elasticities of substitution to analyze the impact on wages in Switzerland caused by the immigration inflows from 2002 to 2008 . As mentioned previously, this time period is deliberately chosen because it marks the period during which the bilateral agreement with the EU on the free movement of workers across borders has been effective.

As a first step, an equation must be derived from the model that allows us to simulate the percentage changes in the average wage of each skill and nativity group due to the above mentioned sequence of immigration flows. Using equation (9), we can take the difference between period $t+p$ and $t$ for all expressions on both sides. Since TFP and relative productivity levels are assumed to be unaffected by immigration, the causal effect on the average wage of any group $(n, b k, j)$ is given by

$$
\begin{aligned}
\left(\frac{\Delta w_{\text {nbkjt }}}{w_{\text {nbkjt }}}\right)_{i} & =(1-\alpha)\left(\frac{\Delta \kappa_{t}}{\kappa_{t}}\right)_{i}+\frac{1}{\sigma_{H L}} \sum_{c q \in C} \sum_{i=1}^{4}\left(s_{F c q i t} \frac{\Delta N_{F c q i t}}{N_{F c q i t}}\right) \\
& -\left(\frac{1}{\sigma_{H L}}-\frac{1}{\sigma_{b}}\right)\left(\frac{1}{s_{b t}}\right) \sum_{q \in b} \sum_{i=1}^{4}\left(s_{F b q i t} \frac{\Delta N_{F b q i t}}{N_{F b q i t}}\right) \\
& -\left(\frac{1}{\sigma_{b}}-\frac{1}{\sigma_{X}}\right)\left(\frac{1}{s_{b k t}}\right) \sum_{i=1}^{4}\left(s_{F b k i t} \frac{\Delta N_{F b k i t}}{N_{b k k i t}}\right) \\
& -\left(\frac{1}{\sigma_{X}}-\frac{1}{\sigma_{I}}\right)\left(\frac{1}{s_{b k j t}}\right)\left(s_{F b k j t} \frac{\Delta N_{F b k j t}}{N_{F b k j t}}\right)-I_{F} \frac{1}{\sigma_{I}}\left(\frac{\Delta N_{F b k j t}}{N_{F b k j t}}\right)
\end{aligned}
$$


where $s_{b t}, s_{b k t}, s_{b k j t}$ and $s_{F b k j t}$ are the shares of the total wage bill paid to the respective groups and $I_{F}$ is an indicator for immigrant workers, i.e. $I_{F}=\{1 \mid n=F\}$ and equals zero for native workers. For a step-by-step description as to how the above equation is derived, see Gerfin and Kaiser (2010, Appendix C). In addition, Appendix D in Gerfin and KaISer (2010) explains how the wage effects can be aggregated up to the higher levels of the nested CES structure.

As a next step, it is now possible to simulate the effects on wages induced by immigration. Equation (10) provides the basic instrument for the calculations. For all simulations, we use the preferred values for the elasticities of substitution obtained from estimation and summarized in Table 3.

\subsection{Long-Run Effects with Full Capital Adjustment}

First, we focus on the long-run implications of immigration which entails complete convergence to the steady-state growth path, and thus, full capital adjustment. In other words, the term $(1-\alpha)\left(\Delta \kappa_{t} / \kappa_{t}\right)_{i}$ in equation (10) is zero, so that we can concentrate on the purely distributional effects and disregard for a moment the macroeconomic effects occurring in the short and medium run. The simulation results are reported in column (1) of Table 4. It is very important to note that all numbers in Table 4 show how the increase in foreign labour supply from 2002 to 2008 affects wages in comparison to the situation in which foreign labour supply remains constant during the same period. Plainly stated, the numbers represent the causal effects of immigration on wages (and not the actual change in wages over the period).

Turning to the effects on natives' wages first, the results imply that immigration flows from 2002 to 2008 have fairly moderate distributional effects in the long run. While the impact on workers with low and medium education is positive $(1.5 \%$ and $1.3 \%)$, the high education group incurs a small wage loss $(-0.9 \%)$ due to immigration. Overall, the increase in foreign labour supply raises the average wage of native workers by $0.4 \%$ in steady state. So there is in fact a small but positive effect on natives' wages in the long run. Turning to the long-run effects on immigrants, we see that the distributional effects across education groups roughly follow the same pattern but their magnitude is larger. This has of course to do with the fact that natives and immigrants are found to be imperfect substitutes for one another. As a most salient result, the steady-state wages of highlyeducated foreign workers are $7.4 \%$ lower due to immigration. In contrast, loweducated and medium-educated foreign workers experience wage gains of $1.1 \%$ and $1.5 \%$ in steady state, respectively. All in all, the immigrant influx from 2002 to 2008 causes the average wage of immigrants to fall by $1.6 \%$ in steady state. 


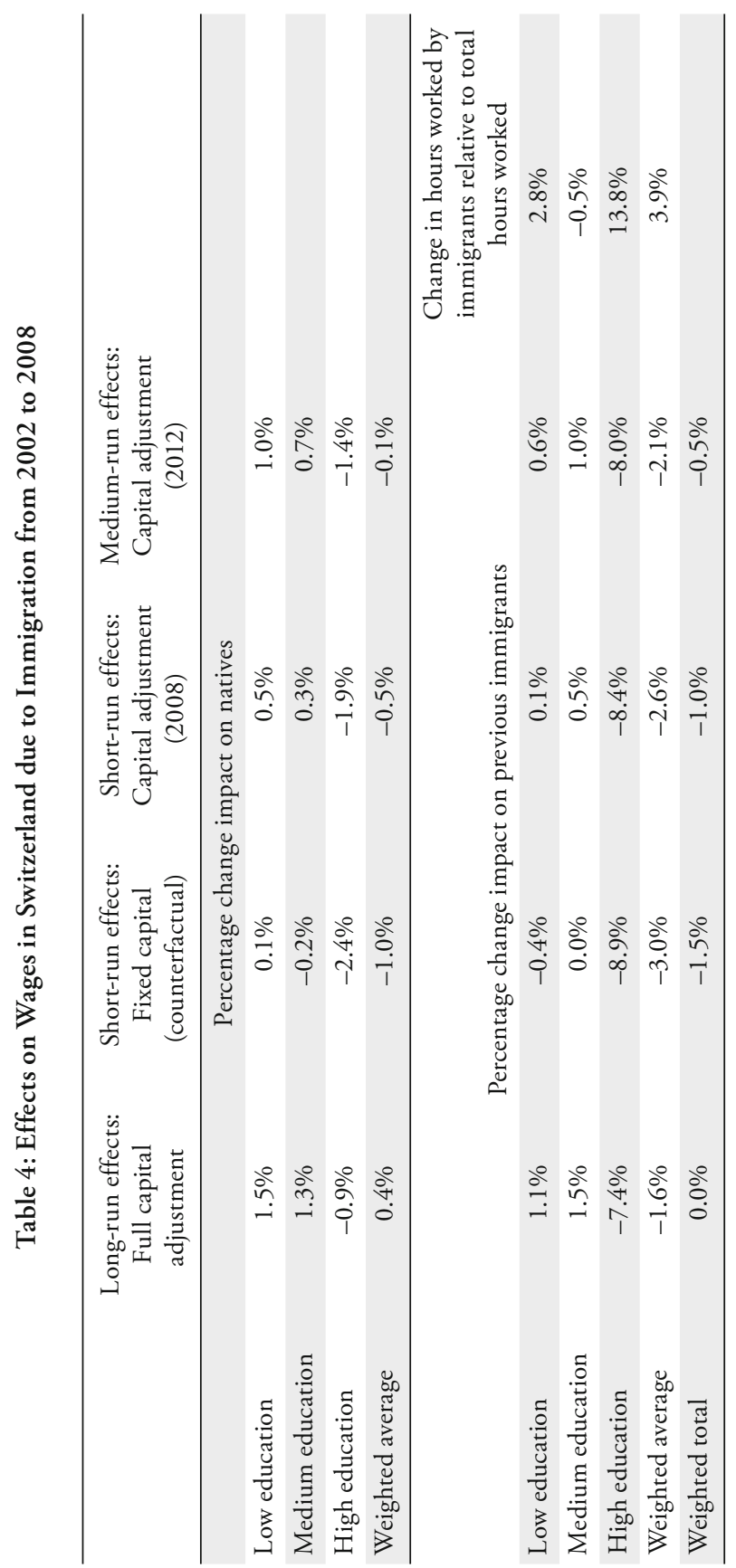


An important question is how sensitive the results are with respect to the elasticities of substitution. We performed sensitivity analyses to evaluate how long-run effects on natives and previous immigrants are affected. Details can be found in Gerfin and Kaiser (2010, Table 8). Two results are worth mentioning. First, $\sigma_{H L}$ and $\sigma_{X}$ only exert a negligibly small influence on the aggregate outcomes of nativity groups, despite having distributional consequences within nativity groups. Second and not surprisingly, $\sigma_{I}$ strongly affects average native and immigrant wages: the larger $\sigma_{I}$ is, the more shifts the adverse impact from previous immigrants to natives. However, even as $\sigma_{I}$ approaches infinity, native workers' wages are barely negatively affected on average. In other words, immigration does not lower average native wages in the long run, even if the elasticity of substitution between natives and immigrants is infinite. Similar finding are reported by Ottaviano and Peri (2007, Table 7) who compute average longrun wage effects for natives and immigrants of $0.1 \%$ and $-0.9 \%$, respectively, when imposing $\sigma_{I}=\infty$.

To sum up the results from the long-run simulation, three important results are obtained. First, natives are on average not negatively affected in the long run as opposed to immigrants, who have lower steady-state wages. This stems from imperfect substitutability between the two groups. Second, the uneven patterns of immigrant inflows across education groups are reflected in the distributional effects on wages. Highly educated workers are exposed to more competition on the labour market due to larger inflows of immigrants with the same skill level. And third, the elasticities of substitution between education groups that are used in the simulation play a very crucial role in determining the distribution of wage effects. On one hand, low substitutability between broad education groups leads to positive cross-effects. That is to say, less educated workers can benefit from large increases in highly educated immigrants. On the other hand, the effects of immigration can easily spill over across education subgroups within the same broad group as consequence of large within-group elasticities. Hence, low-educated workers benefit from the fall in supply of medium-educated immigrants.

\subsection{Short-Run Effects with Fixed Capital}

The traditional analysis usually assumes that the capital stock is perfectly inelastic, as in Borjas (2003, Table 9) and Manacorda et al. (2006, Table 8). Given the immigration inflows over the period from 2002 to 2008, the effect on the average wage equals $(1-\alpha)\left(-\left(\Delta \mathrm{F}_{2002-2008} / \mathrm{N}_{2002}\right)\right)$ which amounts to $0.38(-3.9 \%)=-1.5 \%$. As one can see in column (2) in Table 4, all numbers are scaled down by this constant when compared to the long-run effects in 
column (1). Put differently, this macroeconomic wage effect caused by the decline in the capital-labour ratio affects all workers to the same extent and leaves the relative wage effects across groups unchanged. It is crucial to note that this scenario is rather unrealistic as it assumes no response of capital over the entire period considered. In the section below, this assumption will be dropped.

\subsection{Short-Run and Medium-Run Effects with Capital Adjustment}

To simulate the dynamics of capital adjustment, we need to specify how fast the economy converges back to steady state. Empirical growth literature provides several estimates of the so-called "speed of adjustment" with which the economy converges to steady state. CASELli et al. (1996) and IsLAm (1995) estimate the speed of convergence as being roughly 10 percent per annum. In a more recent study, McQuinN and WHELAN (2007) provide an average estimate of around $7 \%$. ${ }^{6}$ To simulate the adjustment of the capital-labour ratio, OtTaviano and PERI (2008) normalize the balanced growth path to zero and use the following first-order difference equation:

$$
\ln \kappa_{t}=0.9 \ln \kappa_{t-1}-0.9\left(\frac{\Delta F_{t}}{N_{t}}\right) .
$$

They use an adjustment parameter of 0.9 (equivalent to a speed of convergence of $10 \%$ ) and set the impact parameter of the labour supply shock equal to -0.9 which implies that capital adjustment begins in the same period as the labour supply shock occurs.

To simulate the dynamics for Switzerland, we attempt to estimate the speedof-convergence parameter directly from Swiss data. In order to do this, we use the estimating equation of Ottaviano and Peri (2008, equation (24)):

$$
\ln \left(\kappa_{t}\right)=\beta_{0}+\beta_{1} \ln \left(\kappa_{t-1}\right)+\beta_{2}(\text { trend })+\gamma \frac{\Delta F_{t}}{N_{t}}+u_{t}
$$

The capital-labour ratio is constructed using annual data from 1991 to 2007 available from the BFS: the physical capital stock ${ }^{7}$ at constant prices is divided by the

6 For a detailed overview of the convergence literature, see IsLAm (2003).

7 http://www.bfs.admin.ch/bfs/portal/de/index/themen/04/02/04/key/Stock_cap.Document. 83366.xls. 
total actual hours worked drawn from the $\mathrm{AVOL}^{8}$ (Arbeitsvolumenstatistik). The AVOL data is used because it provides a more comprehensive measure of hours worked than the SAKE data. The time trend is approximated by a deterministic linear trend. As for the labour supply shock, we test two specifications: the change in labour supply relative to total labour supply $\left(\Delta N_{t} / N_{t}\right)$, and the change in labour supply due to foreign workers only $\left(\Delta F_{t} / N_{t}\right)$. As Ottaviano and Peri (2008), we attempt to correct for potential endogeneity by instrumenting these variables with the percentage change in the population. The estimation results for $\beta_{1}$ are summarized in Table 5. At first glance, all point estimates yield plausible values for $\beta_{1}$. The speed of convergence defined as $\left(1-\beta_{1}\right)$ is estimated between 0.08 and 0.15 . Unfortunately, only once out of four times can the null hypothesis of $\beta_{1}$ equal to one be rejected at a reasonable significance level. Otherwise, standard errors are too large and render the estimates insignificantly different from one.

Table 5: Estimation Results for $\beta_{1}$, 1991-2007

\begin{tabular}{|c|c|c|}
\hline & $\begin{array}{l}\text { Labour supply shock: } \\
\qquad\left(\frac{\Delta N_{t}}{N_{t}}\right)\end{array}$ & $\begin{array}{l}\text { Labour supply shock: } \\
\qquad\left(\frac{\Delta F_{t}}{N_{t}}\right)\end{array}$ \\
\hline OLS & $\begin{array}{c}0.92 \\
(0.13)\end{array}$ & $\begin{array}{c}0.91 \\
(0.10)\end{array}$ \\
\hline 2SLS & $\begin{array}{c}0.85^{* *} \\
(0.05)\end{array}$ & $\begin{array}{c}0.87 \\
(0.27)\end{array}$ \\
\hline \multicolumn{3}{|c|}{$\begin{array}{l}\text { Significance levels for } H_{0}=1:{ }^{* * *} p<0.01,{ }^{* *} p<0.05,{ }^{*} p<0.1 \\
\text { Observations: } 16 \\
\text { Notes: } 2 \text { SLS uses the percentage change in the population as IV for the } \\
\text { labour supply shock. All standard errors are Newey-West autocorrelation- } \\
\text { robust. }\end{array}$} \\
\hline
\end{tabular}

Two critical comments are necessary. First, the data only covers a short period. Since we are interested in the long-run behaviour of the capital-labour ratio, a solid estimation would require much longer time series data. Second, the problem of biasedness due to serial correlation is inherent, since the lagged dependent

8 http://www.bfs.admin.ch/bfs/portal/de/index/themen/03/02/blank/data/06.Document.68423. xls. 
variable enters as a regressor. The autocorrelation functions of the residual series reveal significantly autocorrelated residuals. Therefore, it must be borne in mind that the results obtained have to be treated with a great deal of caution. However, since the estimated values are roughly consistent with the findings of OTTAVIANO and Peri (2008) and other empirical growth studies mentioned earlier, we define $\beta_{1}=0.9$, and simulate the dynamics of the capital-labour ratio as specified in equation (11) exactly as do Ottaviano and Peri (2008). Figure 1 plots the simulation results against time. It is readily discernable that the labour supply shocks greatly increased in magnitude as of 2003 .

Figure 1: Simulation of the $\log$ Capital-Labour-Ratio

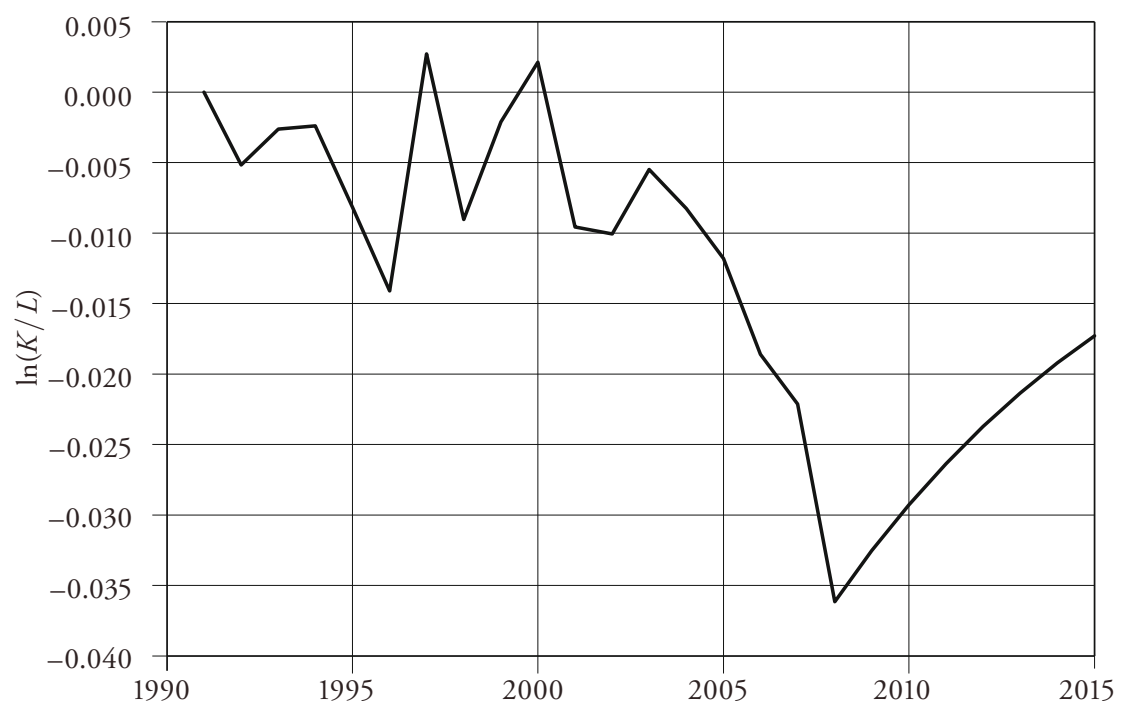

Given the simulated series in Figure 1, it is now possible to calculate the macroeconomic effect of immigration on the average wage. As of 2008, the decline in the capital-labour ratio is equal to $\ln \left(\kappa_{2008}\right)-\ln \left(\kappa_{2002}\right)=-2.6 \%$. Using equation (8), this amounts to an effect of $-1.0 \%=0.38(-2.6 \%)$ on average real wages in Switzerland. Note that this corresponds exactly to the value in the very last row of column (3) in Table 4. In the medium term (in 2012), the the capital-labour ratio is only $1.4 \%$ lower than in 2002 , which translates into a mere $-0.5 \%$ effect on the average wage. Again, this is the number found in the last row of column (4) in 
Table 4. Since we are only interested in the causal effect of immigration from 2002 to 2008, it is assumed that labour supply remains constant after 2008. This can readily be seen in Figure 1, since $\ln \left(\kappa_{t}\right)$ begins to rise monotonically as of 2008 . In sum, the simulated dynamics of the capital-labour ratio show that, as of 2008, $33 \%$ of the distance to the long-run impact is eliminated, and 66\% as of 2012 .

\section{Critical Issues and Limitations}

This section will critically evaluate and discuss the approach and the methods employed in this paper. In doing so, we will point out some crucial problems and limitations and discuss their implications for the results. First, we will deal with the problem of endogeneity which is relevant in the simulation of the wage effects as well as in the estimation of the elasticities of substitution. Second, one underlying assumption of the theoretical framework will be critically discussed: the property of flexible wages.

\subsection{The Endogeneity Problem}

The most important problem with respect to the analysis conducted in this paper is that of endogeneity. As hinted at above, the problem is twofold: first, potential endogeneity biases the simulation of the wage effects of immigration, and second, it obstructs the estimation of the elasticities of substitution. As for the first aspect, the problem arises because the model used for simulation treats the influx of foreign labour as unanticipated, exogenous shocks, meaning that the nature and magnitude of immigrant inflows are entirely determined outside the theoretical framework. This is consistent with the argument that immigration is largely conditioned by "push" factors; the decision to leave the sending country and to move to a particular destination country is, for instance, independent of labour demand in the destination country. It is more likely, however, that immigration flows are indeed influenced by economic conditions in the destination country such as labour demand, i.e. by "pull" factors. For instance, if there is a shortage of skilled workers and labour markets are open, this is likely to attract foreign workers with the qualifications required to serve the needs of domestic firms. Such inflows would then be regarded as endogenous because it is determined by the conditions within the domestic economy. In such a case, there need not be any detrimental effect on wages of natives and settled immigrants, since foreign workers merely fill in job gaps and do not bring about an increased level of competition in the labour market. Treating the increase in foreign labour 
supply as purely exogenous is therefore not innocuous as it tends to overestimates the negative impact on wages.

Second, estimating the elasticities of substitution may also be prone to the endogeneity problem. This stems from the fact that relative labour supply (usually hours worked) is used to explain relative weekly wages in the regression equations. The identifying assumption is thus, that changes in relative wages are caused by shifts in the corresponding relative supply. This holds true as long as demand shocks are not skill-biased or nativity-biased. If changes in demand are asymmetric, the elasticity of substitution cannot be properly estimated. For example, if immigration rates in a particular skill group are high because of high demand and rising wages in that group, the measured impact on the relative wage will be smaller compared to the case where the same immigration inflow is purely exogenous. Since the inverse elasticity of substitution is identified by the variation in relative wages and relative labour supply, estimates will be biased towards zero. This results in an upward bias in the elasticities of substitution, and thus larger adverse spill-over effects across nativity and skill groups. In this paper, we have attempted to resolve this problem by employing available instrumental variables for labour supply, e.g. employment or population. However, given the lack of convincing instruments, the usefulness of IV strategies remains clearly limited.

\subsection{Limitations of the Theoretical Framework}

Another aspect that needs mentioning concerns the underlying assumptions of the structural model. The most important limitation concerns the assumption of flexible wages. In this paper, the theoretical framework is based on a neoclassical production function with perfect competition and labour market clearing in all periods. The latter property entails that there are no frictions in the labour market such that wages adjust to their equilibrium level in every period and no involuntary unemployment prevails. Given the ample evidence of downward rigidities of nominal wages, this assumption is clearly restrictive. First, due to fairness, firms may abstain from lowering wages and cut costs by shrinking the workforce instead (cf. AKerLOF, 1982). Second, collective labour agreements pin down the wages of workers for a certain amount of time. In Switzerland, 1.68 million employees, roughly $50 \%$ of all employees (excluding apprentices), are covered by such agreements (Gesamtarbeitsverträge). ${ }^{9}$ As a result, employers may

9 http://www.bfs.admin.ch/bfs/portal/de/index/themen/03/05/blank/key/gesamtarbeitsvertraege $0 /$ struktur.html. 
be unwilling or unable to lower wages when marginal productivity drops due to immigration shocks and may lay off workers instead. In other words, wages are probably not flexible in responding to sudden changes in labour supply. Instead of driving wages all the way to the new market-clearing equilibrium, immigration shocks may have repercussions on unemployment. If this is the case, wage rigidities incorporated in the model would lead to a smaller impact on wages at the expense of a transitory increase in unemployment.

\section{Conclusions}

The objective of this paper was to investigate how recent immigration inflows have affected wages of native and immigrant workers in Switzerland. The analysis was conducted using the structural "skill-cell approach" as employed by Borjas (2003), Borjas et al. (2007), Ottaviano and Peri (2006), Ottaviano and PeRI (2008). The first important contribution of this paper was to estimate the elasticities of substitution between different types of workers in Switzerland. Regarding natives and immigrants, our results suggest that they are in fact imperfect substitutes, which is in line with the results of Ottaviano and Peri (2006), Ottaviano and Peri (2008), Brücker and Jahn (2008), Felbermayr et al. (2008), D'Amuri et al. (2009), Manacorda et al. (2006). This implies that a rise in foreign labour supply exerts stronger pressure on wages of already settled immigrants than on those of native workers. Regarding different skill levels, the estimates indicate that workers are imperfect substitutes across broad education groups and across different experience groups. In contrast, education subgroups within broad groups are found to have much larger, possibly infinite, elasticities. On the whole, this paper produces a set of parameter values that seems plausible and is largely consistent with the findings of most other studies.

The second important contribution of this paper was to simulate the impact of immigration on wages using the actual increases of foreign labour supply from 2002 to 2008. For the long run, the simulations produce some notable distributional consequences across different types of workers: While previous immigrants incur wage losses, native workers are not negatively affected on average. It is interesting to note that this holds true even if the elasticity of substitution between nativity groups approaches infinity. Across education groups, highlyeducated workers clearly receive the largest amount of competition from new immigrants and therefore face the strongest downward pressure on their wages. For the short run, the simulations predict a negative impact of immigration on the macroeconomic level, meaning that all workers are equally affected. Taking 
into account the dynamic response of physical capital, however, the effect is predicted to die out in the course of the adjustment process.

While the simulations certainly provide an idea as to how immigration affects domestic wages, there are a number of critical aspects associated with the approach chosen in this paper. First, it cannot be ruled out that the simulation results suffer from an endogeneity bias given that the model treats the increases in foreign labour supply as exogenous shocks. If such a bias is present, the true impact on wages is smaller than predicted. Second, the theoretical framework has some clear limitations: it assumes labour-market clearing and flexible wages such that immigration cannot induce unemployment amongst natives and/or previous immigrants. If this assumption does not hold in reality, the actual wage effects would again be smaller than predicted by the simulations. In sum, the numbers produced by the simulations probably represent an "upper bound"; the true impact of immigration on wages is therefore likely to be smaller than predicted in this paper.

With regard to immigration policy, it is important to gain a better understanding as to how domestic labour markets are affected by an increasing number of foreign workers. Since there is an ongoing debate about these issues among economists and policymakers, we believe that this study helps to contribute to the discussion and hope that it instigates further research in the field.

\section{References}

Akerlof, George A. (1982), "Labor Contracts as Partial Gift Exchange", Quarterly Journal of Economics, 97 (4), pp. 543-569.

Altonji, J. G., and D. CARD (1991), "The Effects of Immigration on the Labor Market Outcomes of Less-Skilled Natives", in: NBER (ed.), Immigration, Trade and the Labor Market, pp. 201-234. NBER.

Barro, R. J. (2001), "Human Capital and Growth", American Economic Review, 91 (2), pp. 12-17.

Bodvarsson, O., and H. F. van den Berg (2006), "Does Immigration Affect Labor Demand? Model and Test", Research in Labor Economics, 24, pp. 135-66. Bodvarsson, O., and H. F. van den Berg (2009), The Economics of Immigration, Springer-Verlag, Berlin Heidelberg.

Bodvarsson, O., H. F. van den Berg, and J. J. Lewer (2008), "Measuring Immigration's Effects on Labor Demand: A Reexamination of the Mariel Boatlift", Labour Economics, 15 (4), pp. 560-574. 
Borjas, G. (2003), “The Labor Demand Curve Is Downward Sloping: Reexamining The Impact Of Immigration on the Labor Market", Quarterly Journal of Economics, 118 (4), pp. 1335-1374.

Borjas, G., R. Freeman and L. Katz (1996), "Searching for the Effect of Immigration on the Labor Market", Working paper, NBER No. W5454.

Borjas, G., R. Freeman and L. Katz (1997), "How Much Do Immigration and Trade Affect Labor Market Outcomes?", Brookings Papers on Economic Activity, 1, pp. 1-90.

Borjas, G., J. Grogger, and G. Hanson (2008), "Imperfect Substitution between Immigrants and Natives: A Reappraisal", working paper, NBER No. W13887.

Borjas, G., and L. Katz (2007), "The Evolution of the Mexican-Born Workforce in the United States", in: Geoge Borjas (ed.), Mexican Immigration to the United States.

Brücker, H., and E. J. Jahn (2008), "Migration and the Wage Curve: A Structural Approach to Measure the Wage and Employment Effects of Migration", IZA.

CARD, D. (1990), "The Impact of the Mariel Boatlift on the Miami Labor Market", Industrial and Labor Relations Review, 43 (2), pp. 245-257.

Caselli, F., G. Esquivel, and F. Lefort (1996), "Reopening the Convergence Debate: A New Look at Cross-Country Growth Empirics", Journal of Economic Growth, 1 (3), pp.363-89.

D’Amuri, F., G. Ottaviano, and G. Peri (2009), “The Labor Market Impact of Immigration in Western Germany in the 1990's", CReAM No. 810.

De New, J. P., and K. F. Zimmermann (1994), "Native Wage Impacts of Foreign Labor: A Random Effects Panel Analysis", Journal of Population Economics, 7 (2), pp. 177-92.

Felbermayr, G. J., W. Geis, and W. Kohler (2008), "Restrictive Immigration Policy in Germany: Pains and Gains Foregone?”, working paper, University of Tübingen.

Gerfin, M., and B. Kaiser (2010), "The Effects of Immigration on Wages: An Application of the Structural Skill-Cell Approach", working paper, University of Bern. Available at: http://www.vwl.unibe.ch/papers/dp/dp.1012.pdf.

Haug, W., and D. Müller-Jentsch (2008), Die Neue Zuwanderung, NZZ Libro, Zürich.

Islam, N. (1995), "Growth Empirics: A Panel Data Approach”, The Quarterly Journal of Economics, 110 (4), pp. 1127-70.

Islam, N. (2003), "What Have We Learnt from the Convergence Debate?", Journal of Economic Surveys, 17 (3), pp.309-362. 
LaLonde, R. J., and R. H. Topel (1991), "Immigrants in the American Labor Market: Quality, Assimilation, and Distributional Effects", American Economic Review, 81 (2), pp.297-302.

Manacorda, M., A. Manning, and J. Wadsworth (2006), "The Impact of Immigration on the Structure of Male Wages: Theory and Evidence from Britain", working paper, IZA, No. 2352.

McQuinn, K., and K. Whelan (2007), "Conditional Convergence and the Dynamics of the Capital-Output Ratio", Journal of Economic Growth, 12 (2), pp. 159-184.

Ottaviano, G., and G. Peri (2006), "Rethinking the Effects of Immigration on Wages”, working paper, NBER, No. W12497.

Ottaviano, G., and G. Peri (2007), "The Effects of Immigration on U.S. Wages and Rents: A General Equilibrium Approach", working paper, CReAM, No. 713, University College London.

Ottaviano, G., and G. Peri (2008), "Immigration and National Wages: Clarifying the Theory and the Empirics", working paper, NBER, No. W14188.

Pischke, J.-S., and J. Velling (1997), "Employment Effects of Immigration to

Germany: An Analysis Based on Local Labor Markets", The Review of Economics and Statistics, 79 (4), pp. 594-604.

Ramsey, F. (1928), "A Mathematical Theory of Saving", Economic Journal, 38 (152), pp. 543-559.

SECO (2009), „Auswirkungen der Personenfreizügigkeit auf den Schweizer Arbeitsmarkt: 5. Bericht des Observatoriums zum Freizügigkeitsabkommen Schweiz-EU“, Annual Report.

Solow, R. (1956), "A Contribution to the Theory of Economic Growth", Quarterly Journal of Economics, 70 (1), pp. 65-94.

\section{SUMMARY}

This paper investigates how recent immigration inflows from 2002 to 2008 have affected wages in Switzerland. This period is of particular interest as it marks the time during which the bilateral agreement with the EU on the free crossborder movement of workers has been effective. Since different types of workers are likely to be unevenly affected by recent immigration inflows, we follow the "structural skill-cell approach" as for example employed by BorJAs (2003) and Ottaviano and Peri (2008). This paper provides two main contributions. First, we estimate empirically the elasticities of substitution between different types of workers in Switzerland. Our results suggest that natives and immigrants are 
imperfect substitutes. Regarding different skill levels, the estimates indicate that workers are imperfect substitutes across broad education groups and across different experience groups. Second, the estimated elasticities of substitution are used to simulate the impact on domestic wages using the actual immigration inflows from 2002 to 2008. For the long run, the simulations produce some notable distributional consequences across different types of workers: While previous immigrants incur wage losses $(-1.6 \%)$, native workers are not negatively affected on average $(+0.4 \%)$. In the short run, immigration has a negative macroeconomic effect on the average wage, which, however, gradually dies out in the process of capital adjustment. 